\title{
The Core Proposition of the Treasury Reform and Assignment of Power and Responsibility
}

\author{
Chang Tang \\ School of Public Finance and Tax, Central University of Finance and Economics, Beijing, China
}

\section{Email address:}

tchang@163.com

\section{To cite this article:}

Chang Tang. The Core Proposition of the Treasury Reform and Assignment of Power and Responsibility. International Journal of Finance and Banking Research. Vol. 5, No. 2, 2019, pp. 9-16. doi: 10.11648/j.ijfbr.20190502.11

Received: April 23, 2019; Accepted: May 30, 2019; Published: June 10, 2019

\begin{abstract}
The modern treasury system is the core component of the modern fiscal institution, but it draws little attention and is rarely discussed by domestic academics, until the now-present there still lacks of appropriate discourse. In practice, the functional imbalance of the current treasury system in China is very obvious. One prominent problem is the looseness and vulnerability of budget execution control, which has given rise to the ubiquitous phenomenon of public fund precipitation, frequent budgetary adjustment, tardy payment schedule, and cash rationing. Another problem is the high-level decentralization of government cash balance caused by indiscriminate special fiscal account setup, and the decentralization has greatly weakened the core functions of the national treasury. This paper will clarify two core propositions of institutional reform of the state treasury, including the whole-process budget execution control based on the expenditure cycle, and the government cash management based on the centralization of cash balances. It is expected to construct an appropriate framework of the assignment of power and responsibilities for the treasury system, and promote the deepen reform of the state treasury, building up the coordinating roles of the Ministry of Finance and the People's Bank of China in the modern fiscal institution and supporting the modern treasury system functions.
\end{abstract}

Keywords: Expenditure Cycle, Cash Management, Centralized Management, TSA Mechanism

\section{Introduction}

Although there lacks of adequate discussion on the treasury system, it plays a key role in budget execution control and government cash management, and thus becomes a core component of the modern fiscal institution, especially it involves several core issues of budget execution control based on the expenditure cycle, and the centralization of cash balances, and the assignment of power and responsibilities. Research shows that a sound and coordinating relationship between the Ministry of Finance and the People's Bank is vital to promote the treasury function and respective statutory duty, especially during the financial crisis [1-3].

The state treasury originally referred to the depositories of national wealth, it has evolved into the synonymous of the most formal functions of public fiscal management. One is the fundamental fiscal control over public funds ensures that the source and the use of funds are under valid restraints and regulation of legislative budget authority throughout the budget cycle. Another is the government cash management based on the centralization of cash balances ensures to minimize government financing costs and maximize return on investment of idle funds on the premise of fund security. Because the coordination of fiscal policy and monetary policy is of the major importance, cash management is also a key element of macroeconomic management [4].

The functional imbalance of the current treasury system in China is obvious [5]. One prominent problem is the looseness and vulnerability of budget execution control, which has given rise to the ubiquitous phenomenon of public fund precipitation, frequent budgetary adjustment, tardy payment schedule, and cash rationing. According to the government deposit data released by the People's Bank of China, in the first half of 2018, the monthly average balance of Chinese government deposits remained at around three trillion yuan, which has increased by one trillion yuan compared with the figure in 2012 of the same periods. It well reflects the problem existed in the past government budget work, presenting overvalued budget versus undervalued execution. Another problem is the high-level decentralization of 
government cash balances caused by indiscriminate special fiscal account setup and abuse, which undermined the most important prerequisite for cash management-centralization of cash balances, leading to a series of negative problems of huge amount of precipitation funds, yet enormous debts, austere fund procurement, exacerbate corruption and rigorous power rent-seeking. In recent years, China's fiscal departments have also noticed these problems and organized the clean-up of redundant special fiscal accounts. Depending on the data disclosed by the Treasury Department of the Ministry of Finance, 85,000 fiscal accounts of local governments were withdrawn during the three-year period from 2011 to 2014.

The functional imbalance of the state treasury indicates a deviation happened during China's treasury reform process initiated in 2000. Although China's treasury system and fiscal organization structure vary from other countries, they have universal essential functions focus on budget execution control and government cash management. In order to enhance their effectiveness, the budget execution control shall reign the whole expenditure cycle, and the sound cash management shall apply the centralization of cash balance by setting up a treasury single account (TSA) system [6]. Practice has shown that the Soviet-style treasury model adopted by China before the reform characterized by decentralization management had many drawbacks. Therefore, the original intention of China's reform was correctly setting up a centralization model of "a special account for each government level" (fiscal deposit account). The centralized model, however, due to the special fiscal account abuse has systematic misalignment, leading to the regression of decentralization.

It is foreseeable that the construction of modern fiscal institution will be impaired greatly as long as the systematic misalignment is not completely corrected. Unlike most countries, in addition to tax authorities and taxation department, China's administrative system and treasury system have determined that the Ministry of Finance and the People's Bank of China are two parallel administrative organizations. As the "bank of the government", the People's Bank of China fulfills the functions of the treasury cashier and provides crucial financial services for the government, the inalienable functions of the treasury cash management. The role of "managing the state treasury" assigned to the People's Bank of China as stipulated in the new Budget Law of the People's Republic of China, which was implemented in 2015. However, the debate on the assignment of power and responsibilities between treasury roles has fallen into a stalemate whether in detailed clauses or in practice [7]. If it cannot be settled properly, it will not only hinder the promulgation and implementation of the Enforcement Regulations for the Budget Law of the People's Republic of China, but also affect the coordination on which the treasury functions are highly dependent.

In this context, it is the most crucial and exigent than ever to accurately affirm and clarify the core propositions on deepening the treasury system reform, and to construct an appropriate framework for the assignment of power and responsibilities between treasury roles, rectifying the directional deviation of the treasury reform and facilitating the substantive achievements.

This paper consists of four section. Section 1 and section 2 will discuss the core propositions of the treasury reform, including the whole-process budget execution control based on the expenditure cycle, and the implementation of government cash management based on the centralization of cash balances. Section 3 will discuss the framework of the assignment of power and responsibilities between treasury roles. Section 4 will discuss the supporting measures.

\section{Core Proposition One: Fiscal Control on the Expenditure Cycle Under the Rule of Bottom Lines}

Public funds are derived from taxpayers and are the source of life for all governments to perform public functions. There are two important aspects involved in the public funds. One is the security mechanism, and the other is fiscal control- the most fundamental function of the modern treasury system. Budget execution control is the core element of the fiscal control. If it is not defended, then it is uncontrollable; if it is uncontrollable, then it is not disposable; if it is not disposable, then it cannot be governed [8].

There are three bottom lines of fiscal control rooted in the public funds management:

(1) Budget authority is the government budget applications reviewed and approved by citizens or their representatives. This is another key mechanism for democratic authorization beyond the ballot box mechanism. The fundamental discourse of democracy is authorization [9]. In terms of public finance, it means that the government cannot receive any money from citizens and enterprises, nor pay any expenditure unless it is officially approved by the legislatures representing citizens. Budget authority lies in the modern constitutional principle of people's sovereignty. Its special significance is not only the pro forma establishment of the legitimacy of the government's fiscal authority, but also the essentially supreme legally binding on the activities of the administrative departments throughout the budget year.

Essentially, it is the budget authority that determine what can and cannot be done, what shall be done and what must be done. Legal authority, not financial proposal, is the core essence of the modern public budget system. The legal authority not only reflects the legislature enactment, but also applies legally binding on the administrative departments throughout the budget year, which ensures the consistency between the administrative execution of the budget and the budget authority.

(2) Fiscal decentralization. Fiscal power and responsibilities must be properly assigned among different functional departments to draw the second bottom line for the public fund management. The treasury power such as fiscal account control and cash flow disposal are seemingly trivial 
but actually crucial power, even more powerful than censor, approve and supervise budgets. Under the appeal of "caging the power into institutions", the appropriate assignment of treasury power among treasury roles is key aspect in the construction of power balance system, preventing any particular authority monopolizing all power or controlling the entire process. The most significant is the separation of three major functions during the budget execution process, they are budget authority, accounting record, and fiscal control [10].

From this perspective, the power of instituting budget authority shall be authorized to the legislatures, and the power of budget execution shall be authorized to the administrative departments; within the administrative system, budget execution should be properly assigned among fiscal departments, budget departments, and the People's Bank of China. The questions of "What kind of power are authorized?" and "To whom the matters are accountable?" are the constant focus of the fiscal function construction of the modern treasury system.

(3) Employ supervision. The use of fiscal funds, that is, the flow of public funds from the treasury accounts to the supply account and the implementation of investment, must be placed under the effective supervision of the legislatures. As the third bottom line of public funds, to act of employing supervision is the natural extension of budget authority which is first bottom line, stipulating the treasury departments to regularly report the government bank accounts and cash flows to the People's Congress at all levels respectively. It also requires that a particular treasury department must have prior approval on the total amount of cash outflow by the People's Congress at the corresponding level.

If the National People's Congress has the authority to approve the budget but has no power to supervise the use of public funds, the budget authority will only have a superficial symbolism and will lose its substantial meaning, which is the case in China. Treasury system reform has a great potential to strengthen the power of the National People's Congress [11].

The above three bottom lines and the corresponding treasury control functions all reflect the expenditure cycle which illustrates the dynamic process of the administrative department's budget execution, focusing on the expenditure aspect of the budget execution. Budget execution involves income and expenditure, while budget execution concentrating on the expenditure aspect is more complex than income. For budget execution with determined amount of income, its reliability and effectiveness depend on fiscal control throughout the expenditure cycle. China's current budget theory and practice still lack an explicit concept of expenditure cycle, leading to the failure on the appropriate construction of the whole-process budget execution control, the core proposition of the treasury system reform.

Under this proposition, the fiscal control functions of the state treasury should cover the four basic phases throughout the expenditure cycle:

(1) Budget authority. At this phase, once the budget is approved by the National People's Congress, the state treasury should immediately confirm and record the budget authority and its allocation, including the possibility of the budget approval deviating from the authority in the administrative departments. The confirmed budget authority shall be considered as the highest code for implementing fiscal control over budget execution. The comparison between actual execution and budget authority is the basic method for determining budget compliance, which forms the focus of traditional fiduciary responsibilities. Its effectiveness depends on that whether the two critical mechanisms of budget execution control and compliance audit of the state treasury can be implemented at the management phase of the budget authority. The management phase of the expenditure cycle refers to the stage in which the administrative departments perform budget authority, including the following commitments, verifications and payments. Compliance control of the state treasury at the authority phase is intended to confirm that: (1) public expenditure is officially and explicitly authorized; and (2) each expenditure executive institution has a formal and explicit mandate.

(2) Commitment phase. At this phase, the budget authority binds the obligations of the administrative departments, which indicate that the administrative departments shall make public expenditure decisions within the scope of authority. Signing contracts with upstream suppliers and issuing procurement orders are the major signs of the expenditure commitment. Failure to make a commitment, reduce expenditure or delay commitment indicates administrative inaction in budget execution and must be controlled. In this phase, the control functions of the state treasury should ensure to record and monitor the committed amount, time, budget accounts, specifications and characteristics of goods and services (such as office furniture), officials who are authorized to make commitments, and dates of possible payments, etc. The control functions shall also apply to the cash basis accounting and budgeting. Since the commitment is the source of expenditure that no commitment no expenditure, it is of profound significance for the state treasury to implement effective control. Expenditure executive institutions should also record and monitor the commitment information, exchanging information with fiscal departments. The treasury control at this phase aims to confirm: (1) the proposal for fund expenditure has been approved; (2) the use of funds has been compliant with the budgetary intention; (3) the reserved funds can satisfy various expenditures in the budget; (4) the expenditure follows the correct classification, which means that the proposal for fund expenditure strictly follows the categories identified in the budget.

(3) The verification phase. The budget departments must verify the goods and services delivered by the suppliers, confirm the consistency with the contracts, orders and invoices, calculating the correct payment, and issuing payment orders for the suppliers. At this phase, the expenditure obligations derived from commitment will transform into the accrual expenditure with more powerful legally binding, which is the government's operational debt to the suppliers. The power and responsibilities of finance departments should not appear in the verification phase, but 
the financial statements provided by the finance departments are fundamental and significant, especially for the specific purpose of accurately assessing the debts. As a general rule, it is most reasonable to define "expenditure" in the verification phase, because although the payment has not yet been executed, the legal obligation of the payment has been formed and cannot easily withdraw.

(4) Payment phase. This is the process by which public funds flow from the treasury account to the accounts of suppliers to pay off the operational debts. It is most appropriate to use the direct model of Treasury Single Account (TSA) which is widely adopted by OECD countries. The direct model means that public funds are transferred directly from TSA to the accounts of suppliers or the ultimate payees through the interbank clearing system. This payment model has the lowest risk and most efficiency, which is very different from the advanced payment model adopted in China. The broad payment phase also includes post-payment audits designed to scrutinize and monitor expenditures, as well as to identify and report possible violations.

The treasury control at this phase aims to confirm: (1) Any valid payment obligations happened for accounting records; (2) Appropriate personnel have confirmed that goods and services have been delivered and received as regulated; (3) The invoices and other vouchers required for applying for payments are correct and appropriate; (4) Appropriate payees are determined.

The budgetary accounting refers to the government accounting that records the budgetary operation information at each stage of the expenditure cycle. The accounting scope covers authorization, commitment, verification and payment. The budgetary document as a legal document binds the activities of the administrators, which is the inherent requirement of democratic governance [12]. The preparation of budgetary document and the verification of its statutory compliance must be realized by the budgetary accounting. In general, budgetary accounting is merely a component of government accounting, but it is the most critical element for both policy formulation and budgetary implementation [13]. When supporting and supervising the implementation of the budget, budgetary accounting is also the most crucial technical basis for supporting the treasury control functions. In developed countries, the treasury control functions have already covered all of the stages of the expenditure cycle and deepened into programs: to help review and evaluate public programs through recording, tracking and monitoring individual specific financial transactions at each stage of the expenditure cycle. It is a prerequisite for ensuring the performance of expenditures. In contrast, the current situation in China is far from satisfactory.

\section{Core Proposition Two: Cash Management Based on the Centralization of Cash Balances}

The co-existence of centralized fiscal system and decentralized fiscal management is a distinctive feature of China's fiscal institution [14]. In principle and logically, the advantage of controlling aspect of the centralized system is only reflected with the centralized management. Excessive decentralization of bank accounts, cash balances, fiscal transactions (purchasing, receipt and payment) and accounting records creates management fragmentation and inconsonant cooperation between departments, which will undermine and corrode the control functions of the centralized system. Compared with the decentralized fiscal system (fiscal federalism), the centralization of fiscal decision-making power under the centralized system is much higher, which is conducive to make full use of economies of scale and improve decision-making efficiency. It is also applicable for the internal logic of the centralization of fiscal management functions. Not all of fiscal management functions should be centralized, especially for the fiscal departments, they should not be involved in the budgetary operations implemented by the budget departments during the commitment and verification phases. But the centralization of cash balances through the standard TSA mechanism is the most important exception. When determining the centralization of fiscal transactions, it depends on the transactional level. The indiscriminate centralized payment is misleading and detrimental.

The standard TSA mechanism contains six elements: (1) The government opens and owns the TSA in People's Bank of China. In principle, there shall be one fiscal deposit account for each government level, which is distinguished from the disbursement account and investment account. It is also the most important one of all government fiscal accounts. (2) The government's directly subordinate spending department opens and holds a TSA sub-account in the People's Bank of China. (3) The state treasury authorized subordinate institutions of spending department either open accounts in the People's Bank of China or in designated commercial banks, and the latter are limited to special cases such as remote areas. (4) Institutional accounts must be zero balance accounts (ZBAs), that is, the cash balance must be transferred to the TAS at the end of the daily business. (5) Set the daily ZBAs to zero through the interbank clearing system. (6) At the end of daily business, the People's Bank of China shall summary the overall financial situation of the government, covering all government bank accounts, cash balances, and changes. The current model has deviated from the above standard TSA mechanism quite much, causing negative consequence of high-level of decentralization of cash balances of all levels of government. There are enormous scattered fiscal accounts of low transparency opened in various commercial banks, leading to many thorny difficulties. Given there is a large number of misunderstandings and prejudice against the concentration of cash balances, it shall clarify three key issues:

(1) Centralization of cash balances is a dispensable prerequisite for sound cash management. Practice has evidenced that under the decentralized model, the four major problems that have plagued budget execution control for 
many years will not be solved fundamentally. These four problems are expenditure schedule, fund precipitation, fund scheduling and fiscal supervision. Decentralization will also lead to a long period off-track of government cash management. The appropriate goal of cash management is to ensure that sufficient funds are available at the appropriate time to meet the payment requirements at a reasonable cost and with the least cash balance, rather than earning more income on investment with more cash balances. This goal is closely linked to budgetary implementation.

The specific benefits of centralization include: Ensuring the minimum time interval between receipt and payment in the income collection, which is also an important aspect of the treasury control functions. Use fewer bank accounts managing vast figure of public funds, improving the specialization of cash management, and on the other hand creating distinctive conditions for efficient use of bank clearing, electronic fund transfer and investment facilitation. Reducing additional debt demands and interest payments through automatically adjusting surplus and deficiency of cash requirements of various institutions. Facilitating the People's Bank of China to better formulate and implement monetary policy. Reducing the pressure on internal controls through limited access permission to these accounts. Given the most certain benefits, the concentration of cash balances should be the top priority for the development of China's treasury reform [15].

(2) The "mess" balance sheet issue of People's Bank of China. First, there are enormous cash balance precipitation on the TSA and its sub-accounts, resulting in expensive opportunity costs. This problem in China is very rigorous, but it is neither derived from centralization nor brought by People's Bank of China. It is derived from the functional imbalance of budget execution control. The prominent lack of surplus cash investment.

Residual cash refers to the fiscal deposit balances that exceed the level of safe payment reserves. With the proper control of cash balances, the investment function requires the development of sensible investment policies and procedures within an explicit investment objective framework, including permitted investment categories to ensure an appropriate balance between benefits and risks. The permitted investment categories in most countries mainly include fix-term deposits, national debt reverse repurchase, inter-bank offered in monetary market, high-grade credit bonds, etc. The financing categories mainly include short-term national debts, cash management bonds with flexible term, national debt redemption, inter-bank lending in monetary market, etc. Regardless of profit or loss, investment account information should be fully disclosed, including loans lent to commercial banks.

(3) Centralization of cash balances is the premise and basis for resolving the "mess" balance sheet issue of People's Bank of China. Given the level of cash balances, reinforcing investment is the basic solution of the "mess" issue, but it should not sacrifice centralization. In practice, this means the separation of the investment account from the disbursement account, and the funds flowing into the investment account should merely outflow from and backflow to the TSA and its sub-accounts if necessary. Each specific function of cash management should establish quantifiable goals, especially relevant policies and procedures at the overall government level and institutional levels, including internal control over receipts, deposits and payments, limiting credit policies which are unnecessary or necessary for excessive debts, and designing more effective recalling, recording, and monitoring procedures for receivables. These are key components of a sound cash management system.

\section{The Assignment of Power and Responsibilities Between the Fiscal Departments and the People's Bank of China in the Treasury Management}

The definition of the two core propositions of the treasury reform can be used as an appropriate framework for the assignment of power and responsibilities between the fiscal departments and the People's Bank of China: The fiscal departments are in charge of fiscal control of the budget execution process, and the People's Bank of China is responsible for government cash management, forming relevant collaboration with collecting institutions based on the assignment. The reasons and key points are as follows:

Compatible with core responsibilities and comparative advantages. The budget execution process mainly involves three types of core responsibilities, which are budget execution control, policy implementation and administration of budgetary affairs. The first two are assigned to fiscal departments and the latter one is properly delegated to budget departments; these responsibilities are closely linked to the expenditure cycle. In contrast, the goal of cash management is primarily linked to financial services (including financial regulation) which can be recognized as the pertinent role for People's Bank of China functions as the central bank [16]. In general, the central bank is more suitable than commercial banks as government fiscal agents, involving all of vital government cash management activities, including government securities issuance, debt management, and intervention in the secondary market of government securities [17]. In China, the role of the central bank as a financial service provider defined in government cash management is also consistent with the functions as the "government's bank" and the "banker's bank".

The ascendance of the central bank in government cash management is crucial for fiscal and monetary policy coordination. From the perspective of cash management, it is forbidden to borrow money from the central bank to cover the financial deficit. The government is required to raise funds through the capital market. The central bank can intervene appropriately in the secondary market to regulate monetary policy. Because the fiscal deposits are high powered money, in the context of increasing influence of inflows and outflows of government bank accounts on the 
money supply, the centralized regulation of cash balances through standard TSA mechanism has become indispensable condition for the effective operation of macro-monetary policy, which is conducive to constrain the fiscal policies and debt policies under monetary policy objectives. From the financial transparency perspective, the profit or loss of the central bank shall be deemed as income or expenditure in the budget, which is another key aspect of policy coordination. The reason is simple: In China, the government is the investor and the controller of the entire capital of the central bank, and its operating profit and loss cannot be substantially distinguished from the fiscal revenue and expenditure of fiscal entities.

In addition to the policy coordination, other reasons for the central bank is in charge of standard TSA cash management are: The central bank is responsible for the treasury management representing national government in many countries (including China). The central bank functions as the "banker's bank" with special supervision responsibilities over commercial banks and financial institutions. The two reasons determined that the TSA management performed by the central bank is safer than that of commercial banks. Unlike the central bank, the goal of commercial banks is earning profits, which conflicts with the fundamental purpose of the standard TSA mechanism (centralization of cash balances). The correct goal of cash management is to achieve secure payments with minimal cash balances and at minimum financing costs. This goal relies on the standard TSA mechanism, which is inconsistent with the lucrative motivation of commercial banks that requires as much residual cash investment as possible.

Given the natural predominance of the central bank in terms of security and monetary policy operations, most countries, including OECD member states, are assigning central bank for managing the standard TSA mechanism, the detailed measures are as follows: (1) The central bank opens sub-accounts for all expenditure executive institutions and departments of the government. (2) The central bank records and provides the government with accurate information on the changes in the public funds and the use of funds by the expenditure executive institutions and institutions through the operation and management of the above accounts. (3) The central bank regards the government as its largest shareholder and special client, providing comprehensive financial services that are more beneficial than those for other shareholders and clients.

The central bank is responsible for cash management that requires regardless of payment system, the centralization of cash balances shall cover all government bank accounts used for payment transactions, including accounts of extrabudgetary funds to ensure that all payment transactions are processed through the TSA, also for the residual cash investment [18]. In addition, it is also necessary to transform the advanced payment model into the treasury imprest system, but only for specific conditions, such as remote areas and sporadic expenditures.

The budget execution control dominated by the fiscal departments should avoid impeding the management of standard TSA mechanism by the central bank and the state treasury, preventing the functional corrosion on the People's Bank of China as the government "cashier institution" and the monetary policy maker. On the other hand, the cash management dominated by the People's Bank of China should support the liquidation of the government's payment obligations in a cost-effective manner at appropriate time and place. But it should not attempt to control cash receipt and payment time, or make the payment match the progress of the collection. This is also the case for promoting the coordination between fiscal policy and monetary policy.

The assignment of power and responsibilities based on the core propositions of the treasury reform, that is, the fiscal departments are responsible for the control functions of the state treasury, and the People's Bank of China is responsible for the cash management functions of the state treasury, but this assignment is merely a framework and interrelated. The joint-responsibility and cooperation are the basic principles apply to all aspects and details of the treasury management. This is because the two core functions of the state treasury are interdependent, interactive, and cannot be absolutely separated. Joint-responsibility is also the mainstream model in the world, which is especially effective for the cash management.

\section{Supporting Measures for Core Propositions and the Assignment of Power and Responsibilities}

Budget execution control and centralization of cash balances are respectively dependent on the expenditure cycle-based fiscal compliance control and standard TSA mechanism, but they are not sufficient, unless there are significant supporting measures, including: internal control, technological foundation, information disclosure, incentive mechanism and the Treasury General Ledger System (GLS).

(1) Internal Controls. The public budget provides the first firewall for public fund management to prevent theft and serious embezzlement, supporting the public organizations effectively use resources to obtain returns under their management control [19]. However, budgetary control is not a substitute for budget execution process and internal control in the cash management system, especially policies and procedures designed to monitor the circulation of cash flows within and outside organizations. Internal controls should also cover aspects such as personnel and procurement management. Matters of priority include: Establishing internal control procedure within the spending institutions, eliminating specific budget execution procedures such as special payment command program, and streamlining budget execution and financial control procedures. In particular, the latter should focus on improving and strengthening the commitment control system and combining it with 
realistic budgetary preparation, both of which should be conducted in a transparent manner.

(2) Technical foundation. An effective cash management system relies on a sound banking information infrastructure. Payment methods such as cheques, cash, electronic transfers, and debit cards have a significant impact on the transaction costs of cash outflows. Many modern payment methods, such as electronic transfers, have replaced previously prevailed checks or cash payments. This allows the government to more accurately develop cash flow programs, extend payments, simplify management and accounting procedures, among which are the two most important electronic funds transfer system and the online reporting system. The former allows the government to more accurately formulate cash flow programs, accelerate payments, simplify management and accounting procedures. In terms of opportunity costs and management costs related to accelerating receipts, reducing cash reserves, and saving funds, especially collecting cash balances for investment profitability under the standard TSA mechanism, electronic transfer system is indispensable. Online reporting system can help public finance officials to monitor and obtain accurate and real-time information about cash inflows and outflows, cash balance infomation for short-term investments, and is also conducive to track cheque liquidation and automatically supervise payments.

(3) Incentive mechanism. Effective incentive mechanism should allow public organizations to cope with the overall cash occupancy costs, covering every aspect throughout the whole process from pay-in to pay-out. In practice, this means that public organizations need to pay capital occupancy costs to the state treasury for their non-cash assets occupancy, and for their cash assets occupancy they should pay not less than the deposit interest rates of commercial banks to the state treasury during the same period. The incentive mechanism also requires the introduction of market principles into the relationship between the government and banks: The government obtains interests from commercial banks on its deposits, and pays commercial banks for services such as the payment settlement.

(4) Information disclosure. At present, there is not any formal government cash management information disclosure mechanism in China, which should include cash balances and operational indicators, particularly investment performance disclosed in investment reports. As an important constituent part of a comprehensive investment program, the investment report should disclose all aspects of the investment transactions, including the permitted investment instruments and the deviation between actual performance and performance target. Legally binding on the budget requires the comparison between actual performance and performance target shall consist in the component of the underlying financial statements [20].
(5) Upgrade the functions of the Treasury General Ledger System (GLS). GLS refers to the ledger accounts opened by the treasury for all expenditure executive institutions and departments under the standard TSA mechanism, otherwise known as the control accounts. The basic requirement for the upgrade is to fully and simultaneously record all fiscal transactions, covering all phases of the expenditure cycle, not just payment transactions. This is the foundation for the systematic preparation of financial reports in order to satisfy users' needs. With a higher level of computer control and network operation, the upgraded GLS will ensure the state treasury to record, track and monitor in real-time and simultaneously all activities of the treasury, banks, budget departments and expenditure cycle at all phases.

Among the above five supporting measures, the internal control and classification system emphasize on supporting the budget execution control function of the state treasury. The technical foundation, information disclosure and incentive mechanism focus on supporting the cash management function of the state treasury. Strengthening the two major functions, combined with the assignment of power and responsibilities derived will remain the core propositions of the treasury management reform for the foreseeable future.

\section{Conclusion}

The core proposition of China's treasury reform include two aspects: one is the whole-process budget execution control based on the expenditure cycle, and the other is centralized management based on the standard TSA mechanism. Whole-process budget execution control based on expenditure cycle and the centralization of treasury cash management through standard TSA mechanism are essential requisite conditions for the deepen reform of treasury system operating in the right obit. The two core propositions of the treasury reform can serve as an appropriate framework for the division of the treasury's powers and responsibilities between the Ministry of Finance and People's Bank of China. The Ministry of Finance is mainly responsible for the financial control of the budget execution process, and the People's Bank of China is mainly responsible for the government's cash management. On this basis, together with the tax collection agency. And other roles to carry out related collaboration. The healthy relationship between the Ministry of Finance and the People's Bank of China is also expected to be structured. The appropriate assignment of power and responsibilities between the treasury roles and coordination are crucial to support the functions of the modern treasury system, which is applicable for related supporting reforms. What matters the highest priority is to thoroughly clean up and rectify severely abused fiscal accounts. The bottom line is to ensure minimum transparency to eliminate the serious threat to the public interest. Embedding the treasury reform into the mainstream discourse of fiscal reform is equally crucial. 


\section{References}

[1] Santoro P J (2012). The evolution of Treasury cash management during the financial crisis. Current Issues in Economics and Finance, 18, 1-11.

[2] Hillery, Stephen E. Thompson (2000). The Federal Reserve Banks as Fiscal Agents and Depositories of the United States. Federal Reserve Bulletin, 86, 251-59.

[3] DeCorleto, Donna A and Trimble (2004). Theresa A. Federal Reserve Banks as Fiscal Agents and Depositories of the United States in a Changing Financial Environment. Federal Reserve Bulletin, Autumn, 435-446.

[4] Salvator Schiavo-Campo, Daniel Tommasi (1999). Managing Government Expenditure. Asian Development Bank, 194.

[5] Xiaorong Liu (2017). Current Situation, Problems and Countermeasures of China's Treasury Cash Management. Financial Accounting, 03, 69-74.

[6] Zhenhai Liu, Shan Ji (2018). Budget Performance Management Reform from the Perspective of Treasury. China Finance, 24, 100-101.

[7] Yongjun Wang (2012). China's treasury system reform and firewall construction - the interpretation of the agent-manager dispute. Financial Research, 7, 112-122.

[8] Salvatore Schiavo-Campo (2007). Strengthening Public Expenditure Management in Africa: Criteria, Priorities, and Sequencing. Anwar Shar. Budgeting and budgetary institutions. Washington: The World Bank.

[9] Kinley D. (1905). The Relation of the United States Treasury to the Money Market. American Economic Association Quarterly, 3rd Series, 1, 199-211.

10] Daniel Tommasi (2007). Budget Execution. Edited By Anwar Shar: Budgeting and budgetary institutions. The World Bank.

[11] Tianlong Ma (2019). Research on the Coordination of Central Bank Manager's Treasury and Budget Performance Management. Sub National Fiscal Research, 04, 45-51.

[12] Earl R. Wilson, Jacqueline L (2010). Reck, Susan C. Kattelus. Accounting for Governmental \& Nonprofit Entities. 15 thed. New York: McGraw-HILL/Irwin.

[13] Daniel Tommasi (2007). Budget Execution. Edited By Anwar Shar: Budgeting and budgetary institutions. The World Bank.

[14] Wei Li (2018). A Summary of the Discussion on the Centralized Payment of Financial Treasury. Review of Economic Research, 72, 46-57.

[15] SalvatorSchiavo-Campo, Daniel Tommasi (1999). Managing Government Expenditure. Asian Development Bank.

[16] Taozhen Huang, Liyuan Yin (2018). Game Analysis of the Relationship between Finance and Bank in the Treasury Centralized Payment System. Sub National Fiscal Research, 04, 61-65.

[17] Teresa Ter-Minassian, Pedro P. Parente, Pedro Martinez-Mendez (1995). Setting Up a Treasury in Economies in Transition, IMF.

[18] Salvatore Schiavo-Campo (2007). Budget Preparation and Approval, Edited By Anwar Shar, Budgeting and budgetary institutions. The World Bank.

[19] Williams M (2004. Government cash management: good and bad practice, World Bank Technical Note.

[20] Earl R. And Wilson (2010). Accounting for Governmental and Nonprofit Entities. McGraw-HILL/Irwin. New York. 